\title{
Effect of Okra Pectin on the Sensory, Physicochemical and Microbial Quality of Yoghurt
}

\author{
Manuela Tobil'1, Courage Y. Deh ${ }^{1}$, Jacob K. Agbenorhevi1 ${ }^{*}$, \\ Gilbert O. Sampson ${ }^{2}$, Fidelis M. Kpodo ${ }^{3}$
}

\footnotetext{
${ }^{1}$ Department of Food Science and Technology, Kwame Nkrumah University of Science and Technology, Kumasi, Ghana

${ }^{2}$ Faculty of Vocational Education, University of Education, Kumasi, Ghana

${ }^{3}$ Department of Nutrition and Dietetics, University of Health and Allied Sciences, Ho, Ghana

Email: *jkagbenorhevi@yahoo.com, *jkagbenorhevi.cos@knust.edu.gh
}

How to cite this paper: Tobil, M., Deh, C.Y., Agbenorhevi, J.K., Sampson, G.O. and Kpodo, F.M. (2020) Effect of Okra Pectin on the Sensory, Physicochemical and Microbial Quality of Yoghurt. Food and Nutrition Sciences, 11, 442-456. https://doi.org/10.4236/fns.2020.116032

Received: May 2, 2020

Accepted: June 1, 2020

Published: June 4, 2020

Copyright ( 2020 by author(s) and Scientific Research Publishing Inc. This work is licensed under the Creative Commons Attribution International License (CC BY 4.0).

http://creativecommons.org/licenses/by/4.0/

\section{(c) (i) Open Access}

\begin{abstract}
The objective of this work was to investigate the effect of okra pectin from two genotypes (asha and agbagoma) on the physicochemical, sensory and microbial quality of yoghurt. Okra pectin concentrations (w/w pectin to milk powder ratios) of $0.2 \%, 0.4 \%$ and $0.6 \%$ were used in the yoghurt preparation and its water holding capacity, titratable acidity and $\mathrm{pH}$ were analyzed against a control $(0.0 \%$ pectin) weekly for a month. Consumer acceptability tests for the yoghurt samples were carried out using 50 untrained panellists on a 7-point hedonic scale. Total aerobic microorganisms present in the most preferred samples were enumerated over a four-week period. Results indicated that samples containing $0.2 \%$ asha pectin were most preferred by panelists. Water holding capacity varied significantly with those containing asha pectin higher than agbagoma counterparts and the control. There was a decline in $\mathrm{pH}$ with increasing pectin concentration and over the storage period. Samples containing agbagoma pectin had lower $\mathrm{pH}(3.60$ - 4.32) compared to samples containing asha pectin (4.22 - 4.45). Titratable acidity increased during the storage period and with increasing pectin concentration. After four weeks of storage at $4^{\circ} \mathrm{C}$ sample containing $0.2 \%$ agbagoma pectin had the least microbial count $\left(7.6 \times 10^{5} \pm 4.51 \mathrm{cfu} / \mathrm{g}\right)$, followed by the sample containing $0.2 \%$ asha pectin $\left(2.4 \times 10^{7} \pm 11.14 \mathrm{cfu} / \mathrm{g}\right)$ and the control $\left(8.6 \times 10^{7} \pm 5.57 \mathrm{cfu} / \mathrm{g}\right)$. The study revealed that addition of okra pectin at $0.2 \%$ improved the consumer acceptability of yoghurt and $0.2 \%$ agbagoma pectin inhibits the proliferation of aerobic microbes. Addition of okra pectin also improved the water holding capacity and reduced whey exudation.
\end{abstract}




\section{Keywords}

Okra Pectin, Yoghurt, Syneresis, Consumer Acceptability

\section{Introduction}

Okra (Abelmoschus esculentus) is an important vegetable crop situated in the Malvaceae family and is usually cultivated for its immature pods [1] [2]. The immature pod is characterized by a thick and slimy mucilage which often finds use as thickening agent for soups and stews in most African cuisines and rarely as industrial raw material [3]. It is used in traditional medicine as a dietary meal in the treatment of gastric irritations and dental diseases [3]. Okra is used as a brightening agent in electro deposition of metals. It is also used to reduce friction in pipe in flow as well as preventing flocculation in the fabric and paper industry [4]. Okra mucilage has been found to have potential uses as an extender for serum albumin and as an additive to dried egg white as well as a fat substitute in chocolate, frozen desserts and cookies [5]. The texture of fried yam snack has been improved using okra polysaccharides [6]. Okra polysaccharides have also been used as additives for flour and as a clarifying agent in the sugar cane [3]. The mucilage is used as a thickener to impart characteristic viscosity and smoothness called the okra-effect. This is because it forms a stringiness when dispersed in water. Okra polysaccharides have good emulsion properties in acidic environment and can be used in fruit drinks and acidified dairy products [7]. Okra polysaccharides are predominantly pectins [8]. Pectins are complex heteropolysaccharides containing mainly partially methoxylated galacturonic acid residues [9]. It is extensively distributed in a majority of the fruits and vegetables as the structural unit of fresh cells and the junction between the cells. The pectin molecule is linked by 1,4-D-galacturonic acid which has side chains containing L-rhamnose and other neutrals sugars such as D-galactose and L-arabinose [10]. The viscosity of pectin solutions depends on chemical and physical characteristic of the pectins, on the ionic strength of the solution and on the presence of sugar. According to previous studies, the molecular weight of the pectin affects the gel properties strongly [11]. Other factors that affect the gelation properties of pectin is the length of the pectin side chain as well as the distribution to the methyl group as well as the degree of acetylation. Pectin with shorter side chains gives better gelation properties than pectin with longer side chains [12] [13].

Pectin in the okra pods has functional properties that can be employed in the food industry [8] [14] [15]. These functional properties include; gelling agents, emulsifying agents, water holding capacity and fat substitutes. Pectin can be used in yoghurt to improve the water holding capacity and reduce syneresis in yoghurt. Yoghurt is an acidified milk product that contains calcium that is bioavailable and is also convenient for lactose intolerant individuals [16]. They may also contain probiotics that are live microorganisms which confer health benefits to 
the host when consumed in large amounts [17]. The common yoghurt types found on the market are the Greek yoghurt and the set style yoghurt. The consumption of yoghurt over the years has been on the ascendency [18]. However, syneresis, an undesired occurrence which affects the quality and textual attributes in yoghurt, especially Greek type yoghurt is observed in many instances. Stabilizers are commonly used to combat syneresis and improve the textual properties of yoghurt [19]. Most stabilizers used are hydrocolloids and they include; pectin, alginates, xanthan gum, carrageenan, locust bean gum, gum Arabic, tragacanth and karaya gum [20]. Okra pectin is a novel functional ingredient that has been shown as effective emulsifying candidates in acidic environments with a potential application for acidified food processing [14]. However, the quality of yoghurt as influenced by okra pectin from different genotypes has not been studied.

The objective of this work, therefore, was to study the effect of okra pectin from two genotypes on the physicochemical, sensory and microbial quality of yoghurt.

\section{Materials and Methods}

\subsection{Materials}

The milk powder and sugar were obtained from the local market, Ayigya-Kumasi and the starter culture was obtained from the Beef and Dairy Research Station, Boadi-Kumasi. Okra pectin samples (asha and agbagoma) used were isolated and characterized as previously reported [8]. The asha pectin had $86 \%$ total carbohydrate, $5.5 \%$ protein, $17.2 \%$ Degree of methylation (DM), 39.3\% Degree of acetylation (DA) and Molecular weight $(\mathrm{Mw})$ of $1202 \times 10^{3} \mathrm{~g} / \mathrm{mol}$. The $a g$ bagoma pectin had $66.2 \%$ total carbohydrate, $5.4 \%$ protein, $20.9 \%$ Degree of methylation (DM), 31.7\% Degree of acetylation (DA) and Molecular weight $(\mathrm{Mw})$ of $1419 \times 10^{3} \mathrm{~g} / \mathrm{mol}$ [8]. Chemical reagents used were all of analytical grade.

\subsection{Yoghurt Preparation}

Different concentrations of okra pectin thus $0,0.2 \%, 0.4 \%$ and $0.6 \% \mathrm{w} / \mathrm{w}$ (pectin to milk powder ratio) were added to reconstituted powdered milk and stirred thoroughly with a wooden spatula till there were no lumps. The milk was then pasteurized at $85^{\circ} \mathrm{C}$ for $30 \mathrm{~min}$. While pasteurizing, the milk was stirred to ensure effective homogenization. The pasteurized milk was cooled to $43^{\circ} \mathrm{C}$ and starter culture (Streptococcus thermophilus and Lactobacillus bulgaricus) was inoculated. It was then fermented in an air tight container at $43^{\circ} \mathrm{C}$ for $4 \mathrm{~h}$. The yoghurt was stored at $4^{\circ} \mathrm{C}$ after fermentation [21] pending analysis.

\subsection{Sensory Evaluation}

Consumer acceptability test was carried out using a 7-point hedonic scale with 1 -dislike very much and 7-like very much. The attributes evaluated include 
appearance, taste, aftertaste and thickness and overall acceptability. Fifty (50) untrained panellist were used.

\subsection{Determination of $\mathrm{pH}$, Titratable Acidity (TA) and Water Holding Capacity (WHC)}

The $\mathrm{pH}$ of yoghurt was measured on 7 days' interval with the electrode of a $\mathrm{pH}$ meter standardized with the appropriate buffer. Measurements were made in triplicates and readings were performed at $25^{\circ} \mathrm{C}$ [22].

Titratable acidity was determined using [22] method. $2.5 \mathrm{ml}$ of the yoghurt was placed in a beaker and $25 \mathrm{ml}$ of distilled water added. $\mathrm{NaOH}$ of concentration $0.1 \mathrm{~N}$ was then titrated against the yoghurt. The volume of $\mathrm{NaOH}$ used was recorded as $\mathrm{ml}$ of $0.1 \mathrm{~N} \mathrm{NaOH}$ used. The titratable acidity (TA) was calculated using Formula (1) [22]:

$$
\mathrm{TA}=\frac{\mathrm{ml} \text { of } \mathrm{NaOH} \times 0.1 \times 100}{\text { Weight of aliquot }}
$$

The TA was determined in duplicates, every week for a month.

The method used for water holding capacity was reported by [23] with slight modification. Yoghurt samples $(5 \mathrm{~g})$ were centrifuged at $5000 \mathrm{rpm}$ for $15 \mathrm{~min}$ at $4^{\circ} \mathrm{C}$ and the extent of trapped serum phase quantified and expressed as a percentage of yoghurt volume by measuring the volume of supernatant. Syneresis measurements of yoghurt were made in triplicates. Percentage water holding capacity was calculated using Formula (2):

$$
\% \mathrm{WHC}=\left(1-\frac{W_{1}}{W_{2}}\right) \times 100
$$

where, $W_{1}=$ Weight of whey after centrifugation, $W_{2}=$ Yogurt weight .

\subsection{Determination of Total Aerobic Count}

The total aerobic count (TAC) was carried out to determine the presence or otherwise of aerobic microorganisms in the yoghurt samples containing $0.2 \%$ asha pectin and $0.2 \%$ agbagoma pectin using the modified ISO 4833-1:2013 ISO/TC 147/SC 4/NP-3788:2002 methods. Serial dilutions to the sixth power were prepared using bacteriological peptone as diluent by weighing $10 \mathrm{~g}$ of yoghurt into $90 \mathrm{ml}$ of sterile diluent to obtain the stock from which subsequent dilutions were prepared. An inoculum volume of $0.1 \mathrm{ml}$ of the dilution was inoculated unto sterile plates of Plate Count Agar (OXOID CM0325) using the spread plate technique and incubated for $48 \mathrm{~h}$ at $37^{\circ} \mathrm{C}$. The resulting colonies were recorded and the colony forming units (cfu) calculated.

\subsection{Statistical Analysis}

Results for sensory evaluation were analysed statistically using SPSS version 20 (IBM SPSS Statistics, US). Water holding capacity, $\mathrm{pH}$ and titratable acidity were analysed using multivariate test, followed by Tukey LSD post hoc multiple com- 
parisons. Results for total plate count were analysed using GraphPad Software v.5 (GraphPad Software, San Diego, USA). Comparisons between the different treatments were determined at $5 \%$ level of significance $(p<0.05)$.

\section{Results and Discussion}

\subsection{Consumer Preference and Acceptability}

Variation in the concentration of okra pectin as well as okra variety resulted in varying degree of preference by the sensory panellist in the current study (Table 1; Figure 1; Figure 2). It was observed that, yoghurt sample containing $0.2 \%$ pectin was preferred most for both okra genotypes. However, agbagoma recorded a higher degree of preference (56\%) as opposed to $44 \%$ recorded by asha for the same okra pectin concentration (Figure 1; Figure 2). This result is in agreement with that of [24] who also observed that $0.6 \%$ pectin addition had the least liked sensory properties. Conversely, yoghurt sample containing $0.6 \%$ okra pectin was least preferred for both okra varieties. The preference of samples containing okra pectin over the control gives an indication of the inclination of consumers to purchase these samples over the control.

The current study revealed that okra genotype from which the pectin was extracted and the concentration of incorporation into yoghurt had significant effect on sensory outcomes as perceived by the panellists (Table 1). The mean values for appearance ranged between $4.56 \pm 1.53$ to $5.92 \pm 0.88$, with $0.6 \%$ asha pectin yoghurt recording the lowest appearance rating of neither like nor dislike whiles $0.2 \%$ yoghurt samples of the same okra pectin extract recorded the highest appearance rating of like very much. Interestingly yoghurt sample containing $0.2 \%$ asha pectin was rated significantly higher $(\mathrm{p}<0.05)$ in appearance than the control sample. For samples containing, pectin from agbagoma there was no significant difference in the appearance of the yoghurt samples at varying concentrations as

Table 1. Consumer acceptability of yoghurt incorporated with pectin from asha and agbagoma okra genotypes.

\begin{tabular}{|c|c|c|c|c|c|c|}
\hline Yoghurt & $\%$ Pectin & Appearance & Taste & Aftertaste & Thickness & $\begin{array}{c}\text { Overall } \\
\text { acceptability }\end{array}$ \\
\hline Control & 0.0 & $5.23 \pm 1.28^{\mathrm{a}}$ & $5.30 \pm 1.15^{\mathrm{a}}$ & $4.93 \pm 1.20^{\mathrm{a}}$ & $3.77 \pm 1.33^{\mathrm{a}}$ & $5.03 \pm 1.21^{\mathrm{a}}$ \\
\hline Asha & 0.2 & $5.92 \pm 0.88^{b}$ & $6.00 \pm 0.83^{c}$ & $5.76 \pm 0.85^{\mathrm{c}}$ & $5.80 \pm 1.03^{b}$ & $6.18 \pm 0.69^{c}$ \\
\hline Agbagoma & 0.2 & $5.17 \pm 1.49^{\mathrm{a}}$ & $5.33 \pm 1.21^{\mathrm{a}}$ & $4.97 \pm 1.38^{\mathrm{a}}$ & $4.93 \pm 1.68^{\mathrm{b}}$ & $5.34 \pm 1.17^{\mathrm{a}}$ \\
\hline Asha & 0.4 & $5.56 \pm 1.20^{\mathrm{b}}$ & $5.08 \pm 1.35^{\mathrm{b}}$ & $4.78 \pm 1.53^{\mathrm{b}}$ & $5.88 \pm 0.96^{\mathrm{b}}$ & $5.34 \pm 1.14^{\mathrm{b}}$ \\
\hline Agbagoma & 0.4 & $5.10 \pm 1.32^{\mathrm{a}}$ & $5.17 \pm 1.29^{a}$ & $4.90 \pm 1.16^{\mathrm{a}}$ & $3.43 \pm 1.43^{\mathrm{a}}$ & $4.72 \pm 1.22^{\mathrm{a}}$ \\
\hline Asha & 0.6 & $4.56 \pm 1.53^{\mathrm{a}}$ & $4.40 \pm 1.50^{\mathrm{a}}$ & $4.42 \pm 1.47^{\mathrm{a}}$ & $4.04 \pm 1.80^{\mathrm{a}}$ & $4.40 \pm 1.36^{\mathrm{a}}$ \\
\hline Agbagoma & 0.6 & $5.30 \pm 1.29^{\mathrm{a}}$ & $5.40 \pm 1.16^{\mathrm{a}}$ & $4.80 \pm 1.43^{\mathrm{a}}$ & $4.17 \pm 1.49^{\mathrm{ab}}$ & $4.97 \pm 1.12^{\mathrm{a}}$ \\
\hline
\end{tabular}

Values are mean $\pm \mathrm{SD}$. ${ }^{\mathrm{a}-\mathrm{c}}$ Values with different superscripts in the same column are significantly different ( $\mathrm{p}$ < 0.05). Scale: 1-Dislike very much; 2-Dislike moderately; 3-Dislike slightly; 4-Neither like nor dislike; 5-Like slightly; 6-Like moderately; 7-Like very much. 


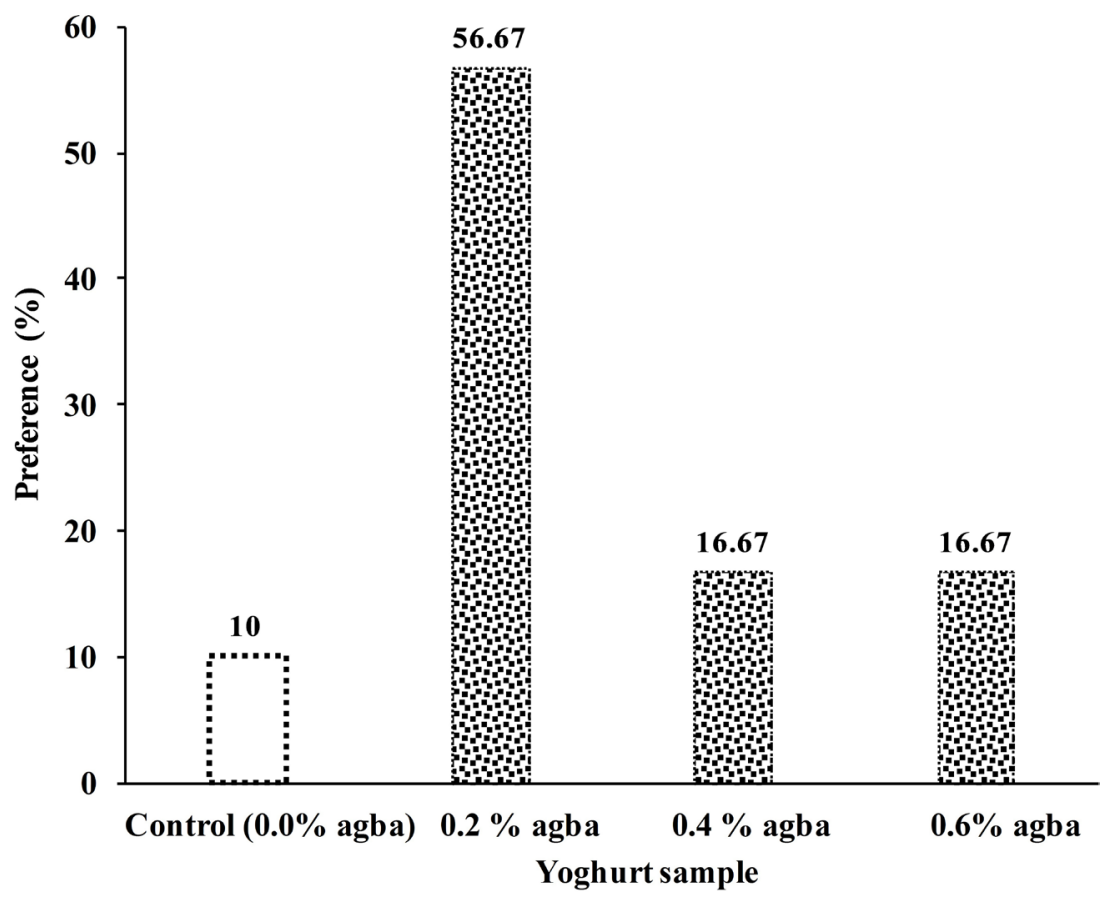

Figure 1. Consumer preference of control and yoghurt samples containing agbagoma pectin.

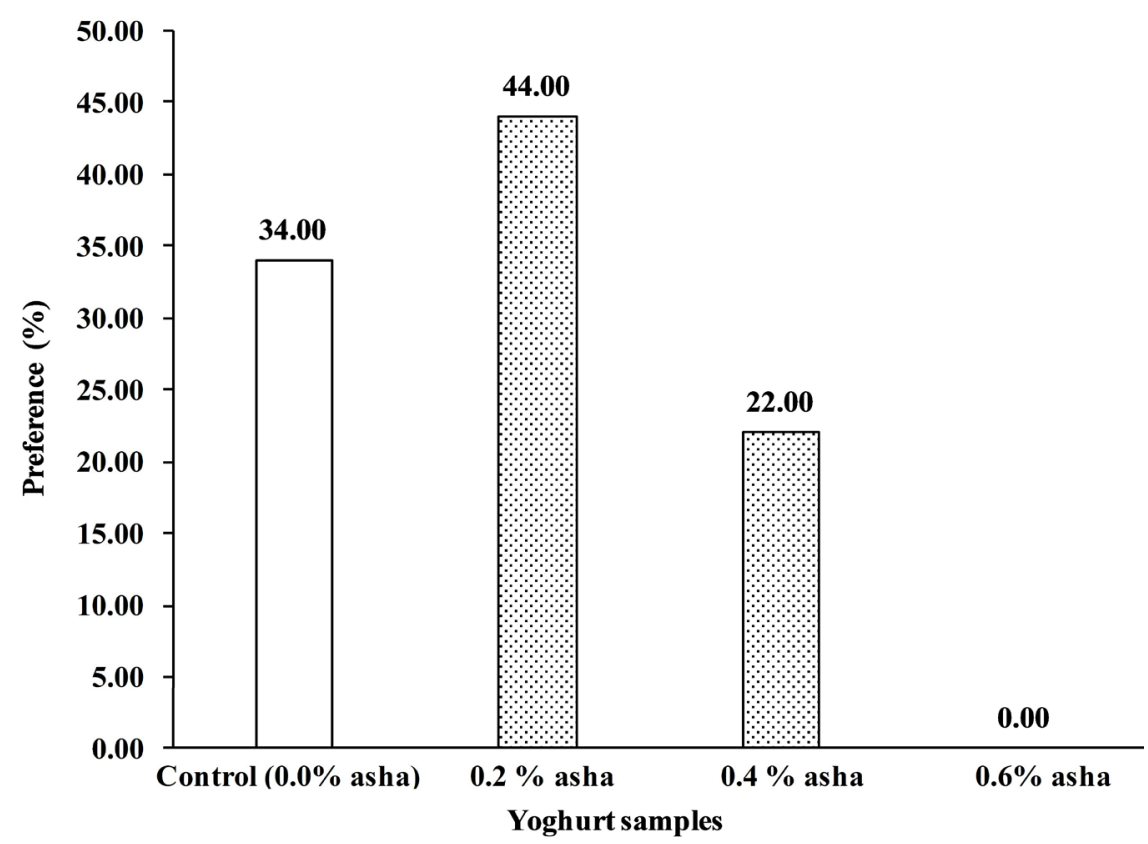

Figure 2. Consumer preference of control and yoghurt samples containing asha pectin.

well as the control sample.

With regards to taste of the yoghurt, the mean values ranged between $4.40 \pm$ 1.50 to $6.00 \pm 0.83$ with yoghurt with $0.6 \%$ asha pectin recording the least mean value of neither like nor dislike whiles $0.2 \%$ asha yoghurt recorded the highest mean value of like very much according to the hedonic scale. sample with $0.2 \%$ asha pectin and $0.2 \%$ agbagoma pectin was most liked in terms of taste, however 
the difference between that sample and the control. This signifies that pectin at $0.2 \%$ can be used to improve the taste of yoghurt. The yoghurt containing $0.4 \%$ agbagoma pectin and $0.6 \%$ asha and agbagoma pectin were least liked as compared to the control. This finding is not consistent with the findings of [25] who stated that the improvement of the taste of yoghurt was proportional to the pectin addition rate from $0 \%-0.6 \%$. The sour taste of yoghurt is as a result of the fermentation of lactose into lactic acid by two bacteria strains namely Lactobacillus bulgaricus and Streptococcus thermophiles. Specific yoghurt flavour is contributed by the acetaldehyde during the lactic acid fermentation [26]. Flavour is the overall impression of food and is the combination of aromatics, taste and mouthfeel. The milk proteins and pectin interact in a way that causes the unfolding of the milk proteins making hydrophilic groups accessible. These hydrophobic groups serve as extra sites for the binding of volatile compounds [27]. Samples containing the $0.6 \%$ had the least liked aftertaste. This finding corresponds with [25] who found that yoghurt with $0.6 \%$ pectin had the least liked aftertaste. Studies by [24] found that the addition of stabilizers above 3.5\% resulted in undesired flavours.

The thickness of samples with $0.4 \%$ asha pectin was most liked but there was no significant difference between that and the control while the sample containing $0.6 \%$ pectin was least liked. For samples containing agbagoma pectin, samples containing $0.2 \%$ pectin was liked most as compared to the control. There was no significant difference in the overall acceptability of samples containing agbagoma pectin. However, sample containing $0.6 \%$ asha pectin had the least overall acceptability. This result is in agreement with that obtained by [24] who stated that $0.6 \%$ pectin addition has the least liked sensory properties on the overall. The results make it evident that pectin from different varieties of okra have significantly different impacts on the consumer acceptability of yoghurt.

\subsection{Physicochemical Properties}

Water holding capacity of protein gels in yoghurt is important because it is directly related to syneresis which is an undesirable occurrence. Syneresis is due to the intrinsic instability of gels. The lower the water holding capacity, the higher the occurrence of syneresis [23]. Sample containing 0.4\% agbagoma pectin had the highest water holding capacity on the first day of analysis, however, the difference was not significant with the other samples. There was a gradual decline in the water holding capacity of the samples over the week (Table 2). After four weeks of storage at $4^{\circ} \mathrm{C}$, sample containing $0.4 \%$ had the highest water holding capacity which was significantly different from the samples containing $0.0 \%$ and $0.2 \%$ agbagoma pectin. Sample containing no pectin (control) had the lowest water holding capacity (Table 2 ).

There were significant differences in water holding capacity observed between the samples containing asha pectin. There were no significant differences between the water holding capacity between $0.2 \%$ and $0.0 \%$ on the first day of storage. 
Table 2. Water holding capacity (\%) of yoghurt samples incorporated with asha and agbagoma pectin.

\begin{tabular}{ccccccc}
\hline Yoghurt & \% Pectin & Day 1 & Day 7 & Day 14 & Day 21 & Day 28 \\
\hline Control & 0.0 & $50.10 \pm 1.84^{\mathrm{Aa}}$ & $46.46 \pm 0.73^{\mathrm{Ba}}$ & $45.79 \pm 0.98^{\mathrm{Ba}}$ & $43.24 \pm 1.77^{\mathrm{Ca}}$ & $40.43 \pm 0.33^{\mathrm{Da}}$ \\
Asha & 0.2 & $87.40 \pm 0.20^{\mathrm{Ab}}$ & $86.47 \pm 0.23^{\mathrm{Bc}}$ & $86.13 \pm 0.12^{\mathrm{Bb}}$ & $86.07 \pm 0.12^{\mathrm{Bb}}$ & $85.33 \pm 0.31^{\mathrm{Bb}}$ \\
Agbagoma & 0.2 & $52.04 \pm 3.15^{\mathrm{Aa}}$ & $51.83 \pm 1.29^{\mathrm{Ab}}$ & $51.18 \pm 0.01^{\mathrm{Ac}}$ & $50.50 \pm 1.27^{\mathrm{Ac}}$ & $43.16 \pm 0.64^{\mathrm{Bc}}$ \\
Asha & 0.4 & $90.27 \pm 0.42^{\mathrm{Ad}}$ & $90.27 \pm 0.31^{\mathrm{Ad}}$ & $90.07 \pm 0.12^{\mathrm{Ad}}$ & $89.87 \pm 0.23^{\mathrm{Ad}}$ & $89.07 \pm 0.31^{\mathrm{Ad}}$ \\
Agbagoma & 0.4 & $54.86 \pm 2.16^{\mathrm{Ab}}$ & $52.91 \pm 0.13^{\mathrm{Bb}}$ & $51.38 \pm 0.29^{\mathrm{Cc}}$ & $45.07 \pm 0.77^{\mathrm{De}}$ & $46.61 \pm 0.55^{\mathrm{Ee}}$ \\
Asha & 0.6 & $81.20 \pm 1.04^{\mathrm{Ac}}$ & $80.53 \pm 0.50^{\mathrm{Ae}}$ & $79.67 \pm 1.45^{\mathrm{Be}}$ & $79.47 \pm 1.29^{\mathrm{Bf}}$ & $78.73 \pm 1.63^{\mathrm{Bf}}$ \\
Agbagoma & 0.6 & $50.48 \pm 2.96^{\mathrm{Aa}}$ & $47.59 \pm 1.12^{\mathrm{Ba}}$ & $43.76 \pm 0.09^{\mathrm{Cf}}$ & $40.85 \pm 1.01^{\mathrm{Dg}}$ & $45.98 \pm 0.13^{\mathrm{Eg}}$ \\
\hline
\end{tabular}

Values are Mean \pm SD of triplicate determinations. ${ }^{\mathrm{A}-\mathrm{E}}$ Values in the same row with different superscript letters are significantly different $(\mathrm{p}<0.05)$. ${ }^{\mathrm{a}-\mathrm{g}}$ Values in the same column with different superscript letters are significantly different $(\mathrm{p}<0.05)$.

However, there were differences observed on the $7^{\text {th }}$ and $21^{\text {st }}$ day. The sample with $0.4 \%$ pectin exhibited the highest water holding capacity. The water holding capacity increased with increasing pectin concentration until $0.6 \%$ where there was a sharp decrease in the water holding capacity (Table 2). This sample exhibited lesser water holding capacity than the control. Studies by [28] found that increasing pectin content increased the water holding capacity and the increase was directly proportional to the pectin content. This is as a result of the interaction between proteins and water. The intrinsic factors that could affect the water holding capacity include the protein conformation and hydrophobicity of protein. The presence of pectin further helps in binding of water and improving the texture. The water is trapped in the matrix of the pectin as it forms a three dimensional structure. Pectin also interacts with proteins hence, increasing hydration properties and gel stability [28]. During the storage time, there were slight reductions in the water holding capacity among the samples. However, the sample with $0.4 \%$ asha pectin showed the highest water holding capacity $(89.07 \%)$ after 28 days of storage while the least was observed by the sample with $0.6 \%$ agbagoma pectin. [26] also observed slight reduction in the water holding capacity during the storage period. Water holding capacity of food is very important as it imparts the texture and flavour of food. Sample containing asha pectin generally exhibited higher water holding capacity compared to the agbagoma pectin. Highest water holding capacity observed for the samples containing asha was $90.27 \%$ which was exhibited by the sample containing $0.4 \%$ pectin on the first day of storage as against $54.84 \%$ recorded by the sample containing agbagoma pectin on the first day of storage. Pectin from different varieties of okra exhibited different water holding capacity. According to [8], pectins from different varieties of okra have different structures and as such have different functionalities. And as such, for a desired functionality, the appropriate okra genotype should be selected.

The acidity of yoghurt is an important quality parameter that indicates the 
shelf life, palatability and consumer acceptance [29] [30]. The production of lactic acid (predominant acid in yoghurt) during the fermentation of yoghurt is responsible for the formation of gel network which gives yoghurt its characteristic texture [31]. The lactic acid produced also confers the characteristic flavour and taste to the yoghurt. Reduction in $\mathrm{pH}$ after fermentation is however not desired since it leads to excess sourness, wearing off and textural defects. Hence, it is very important to closely monitor the $\mathrm{pH}$ and titratable acidity to assure the consumer of consistency in product characteristics. The usual acceptable $\mathrm{pH}$ of yoghurt is 4.5. Several reports indicate that the rapid decrease in $\mathrm{pH}$ at the beginning of fermentation is of importance for the quality of the end product [29]. There was a decline in $\mathrm{pH}$ in the samples containing agbagoma pectin. Increasing concentration of the okra pectin leads to a resultant decrease in the $\mathrm{pH}$ of the samples. The $\mathrm{pH}$ decreased slightly for all samples with the sample containing $0.4 \%$ having the lowest $\mathrm{pH}$ after the storage period (Table 3).

For samples containing asha pectin, the change in $\mathrm{pH}$ was directly proportional to the rate of pectin addition. The $\mathrm{pH}$ increased with increasing pectin concentration. There were no significant differences in $\mathrm{pH}$ of all the samples on the $14^{\text {th }}$ day of storage. During the time of storage, there was slight reduction in the $\mathrm{pH}$ in all the samples (Table 3).

The reduction in $\mathrm{pH}$ on storage can be attributed to the utilization of residual carbohydrate by viable microorganisms. The decline in $\mathrm{pH}$ values may also be due to continued fermentation by lactic acid bacteria and the contribution of acidity of the added stabilizer [28]. [32] recorded a pH decreased from 6.70 to 4.34 from the time of inoculation of the bacterial culture to the completion of the yoghurt manufacturing processing. Streptococcus thermophilus and Lactobacillus bulgaricus are the bacteria strains responsible for converting lactose into lactic acid in yoghurt. They live in symbiosis and there exists a synergy between the two bacteria which relates to a mutual stimulation. This stimulation relates mainly to the growth, acidification, and the production of aromatic compounds.

Table 3. $\mathrm{pH}$ of yoghurt samples incorporated with okra pectin at different concentrations.

\begin{tabular}{|c|c|c|c|c|c|c|}
\hline Yoghurt & $\%$ Pectin & Day 1 & Day 7 & Day 14 & Day 21 & Day 28 \\
\hline Control & 0.0 & $4.46 \pm 0.01^{\mathrm{Aa}}$ & $4.44 \pm 0.00^{\mathrm{Aa}}$ & $4.41 \pm 0.01^{\mathrm{Aa}}$ & $4.37 \pm 0.01^{\mathrm{Aa}}$ & $4.32 \pm 0.02^{\mathrm{Aa}}$ \\
\hline Asha & 0.2 & $4.45 \pm 0.00^{\mathrm{Aa}}$ & $4.44 \pm 0.01^{\mathrm{Aa}}$ & $4.39 \pm 0.01^{\mathrm{Aa}}$ & $4.35 \pm 0.01^{\mathrm{Aa}}$ & $4.30 \pm 0.01^{\mathrm{Aa}}$ \\
\hline Agbagoma & 0.2 & $4.32 \pm 0.00^{\mathrm{Aa}}$ & $4.17 \pm 0.00^{\mathrm{Aa}}$ & $4.05 \pm 0.00^{\text {Aaa }}$ & $3.96 \pm 0.01^{\mathrm{Bb}}$ & $3.61 \pm 0.00^{\mathrm{Bb}}$ \\
\hline Asha & 0.4 & $4.43 \pm 0.01^{\mathrm{Aa}}$ & $4.42 \pm 0.01^{\mathrm{Aa}}$ & $4.41 \pm 0.02^{\mathrm{Aa}}$ & $4.33 \pm 0.01^{\mathrm{Aa}}$ & $4.25 \pm 0.01^{\mathrm{Aa}}$ \\
\hline Agbagoma & 0.4 & $4.22 \pm 0.01^{\mathrm{Aa}}$ & $4.09 \pm 0.00^{\mathrm{Aa}}$ & $4.02 \pm 0.01^{\mathrm{Aa}}$ & $3.94 \pm 0.00^{\mathrm{Bb}}$ & $3.60 \pm 0.00^{\mathrm{Bb}}$ \\
\hline Asha & 0.6 & $4.41 \pm 0.00^{\mathrm{Aa}}$ & $4.41 \pm 0.01^{\mathrm{Aa}}$ & $4.39 \pm 0.01^{\mathrm{Aa}}$ & $4.34 \pm 0.01^{\mathrm{Aa}}$ & $4.22 \pm 0.01^{\mathrm{Aa}}$ \\
\hline Agbagoma & 0.6 & $4.23 \pm 0.00^{\mathrm{Aa}}$ & $4.10 \pm 0.00^{\mathrm{Aa}}$ & $4.08 \pm 0.00^{\mathrm{Aa}}$ & $3.94 \pm 0.00^{\mathrm{Bb}}$ & $3.66 \pm 0.00^{\mathrm{Bb}}$ \\
\hline
\end{tabular}

Values are Mean \pm SD of at least triplicate determinations. ${ }^{\mathrm{A}-\mathrm{E}}$ Values in the same row with different superscript letters are significantly different $(\mathrm{p}<0.05) .{ }^{\mathrm{a}-\mathrm{g}}$ Values in the same column with different superscript letters are significantly different $(\mathrm{p}<0.05)$. 
Streptococcus thermophilus is stimulated by the amino acids and small peptides coming from the proteolytic activity of Lactobacillus bulgaricus. The stimulation of $L$. bulgaricus is allotted to formic acid, pyruvic acid, and carbon dioxide produced by $S$. thermophilus. Both microbial species are homofermentative bacteria, which produce lactic acid starting from lactose milk. The production of lactic acid results in a lowering $\mathrm{pH}$. Some reports [33] attributed the reduction in $\mathrm{pH}$ to microbial activity while others [34] attributed the post acidification during storage as due to the presence of $\beta$-galactosidase which is active at temperatures of $0^{\circ} \mathrm{C}-5^{\circ} \mathrm{C}$. Furthermore, [35] suggested that the drop in $\mathrm{pH}$ during storage was as a result of the activities of residual enzymes produced by starter culture during fermentation.

The $\mathrm{pH}$ range of samples containing asha pectin was $4.45-4.22$. The samples containing agbagoma pectin recorded $\mathrm{pH}$ of 4.32 - 3.60 during the storage period. Yoghurt samples containing agbagoma pectin exhibited lower $\mathrm{pH}$ (Table 3 ).

There were significant differences between the titratable acidity of the samples $(\mathrm{p}<0.05$; Table 4). Titratable acidity refers to the measure of the total acid contained in a food. Titratable acid is sometimes referred to as total acid. This is different from $\mathrm{pH}$ of food which is the logarithm of the concentration of free hydrogen ions. The titratable acidity is a better predictor of the acid impact on flavour. The ability of microorganisms to grow in a particular food is more dependent on the $\mathrm{pH}$ than titratable acidity. The titratable acidity of the samples increased with increasing pectin concentration. A previous study [25] also observed an increase in titratable acidity with increase in pectin concentration. According to [24], addition of stabilizer slightly increased the rate of acid development. There was an increase in the titratable acid content during the storage period which could be due to the accumulation of organic acids. This was also observed by [26].

Samples containing asha pectin exhibited higher titratable acidity as compared to the sample containing agbagoma pectin. Differences observed is as a result of

Table 4. Changes in titratable acidity (\%) during storage period.

\begin{tabular}{|c|c|c|c|c|c|c|}
\hline Yoghurt & $\%$ Pectin & Day 1 & Day 7 & Day 14 & Day 21 & Day 28 \\
\hline Control & 0.0 & $39.20 \pm 0.00^{\mathrm{Aa}}$ & $39.40 \pm 0.28^{\mathrm{Aa}}$ & $39.40 \pm 0.28^{\mathrm{Aa}}$ & $40.00 \pm$ & \\
\hline Asha & 0.2 & $39.80 \pm 0.28^{\mathrm{Aa}}$ & $40.00 \pm 0.00^{\mathrm{Aa}}$ & $41.00 \pm 0.28^{\mathrm{Bb}}$ & $41.20 \pm 0.00^{\mathrm{Bb}}$ & $42.20 \pm 0.28^{\mathrm{Ca}}$ \\
\hline Agbagoma & 0.2 & $12.60 \pm 0.28^{\mathrm{Ab}}$ & $13.00 \pm 0.28^{\mathrm{Bb}}$ & $13.80 \pm 0.28^{\mathrm{Bc}}$ & $15.20 \pm 0.00^{\mathrm{Cc}}$ & $16.00 \pm 0.00^{\mathrm{Db}}$ \\
\hline Asha & 0.4 & $40.20 \pm 0.28^{\mathrm{Aa}}$ & $40.60 \pm 0.28^{\mathrm{Aa}}$ & $40.40 \pm 0.57^{\mathrm{Aa}}$ & $41.80 \pm 0.28^{\mathrm{Bb}}$ & $43.60 \pm 0.00^{\mathrm{Bc}}$ \\
\hline Agbagoma & 0.4 & $13.60 \pm 0.57^{\mathrm{Ac}}$ & $14.40 \pm 0.57^{\mathrm{Bc}}$ & $15.20 \pm 0.00^{\mathrm{Bd}}$ & $15.60 \pm 0.00^{\mathrm{Bd}}$ & $16.40 \pm 0.00^{\mathrm{Cb}}$ \\
\hline Asha & 0.6 & $41.20 \pm 0.57^{\mathrm{Ab}}$ & $41.60 \pm 0.00^{\mathrm{Ab}}$ & $41.40 \pm 0.28^{\mathrm{Ab}}$ & $42.40 \pm 0.00^{\mathrm{Be}}$ & $44.00 \pm 0.57^{\mathrm{Cd}}$ \\
\hline Agbagoma & 0.6 & $14.00 \pm 0.00^{\mathrm{Ac}}$ & $14.80 \pm 0.00^{\mathrm{Ac}}$ & $15.20 \pm 0.00^{\mathrm{Bd}}$ & $15.60 \pm 0.00^{\mathrm{Bd}}$ & $16.40 \pm 0.00^{\mathrm{Cb}}$ \\
\hline
\end{tabular}

Values are Mean \pm SD of duplicate determinations. ${ }^{A-E}$ Values in the same row with different superscript letters are significantly different $(p<0.05){ }^{a-g}$ Values in the same column with different superscript letters are significantly different $(\mathrm{p}<0.05)$. 

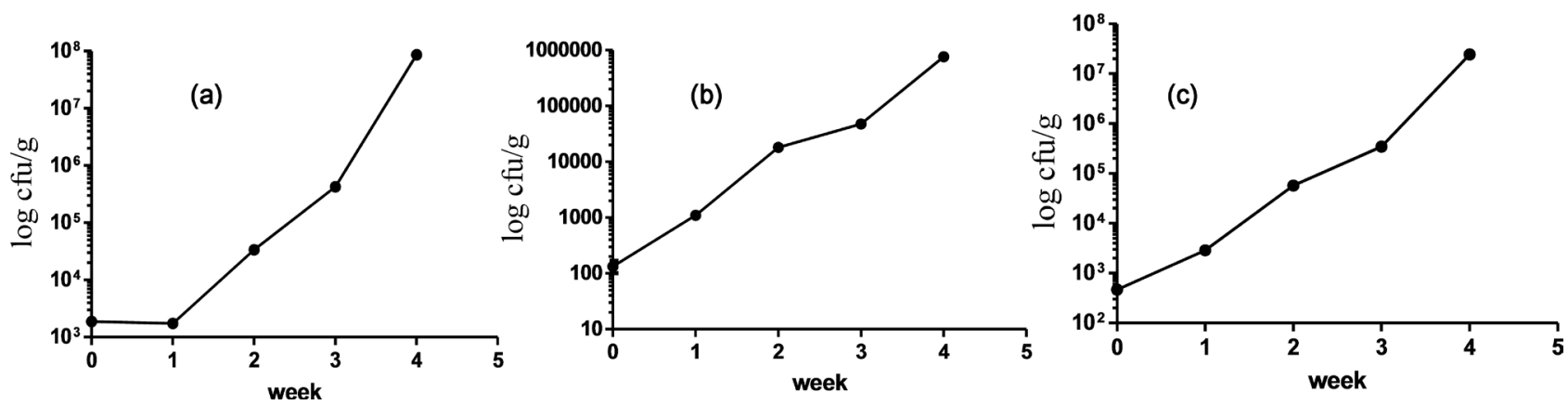

Figure 3. Microbial load (total aerobic count) of yoghurt samples: (a) control, (b) agbagoma and (c) asha over a four (4) week study period.

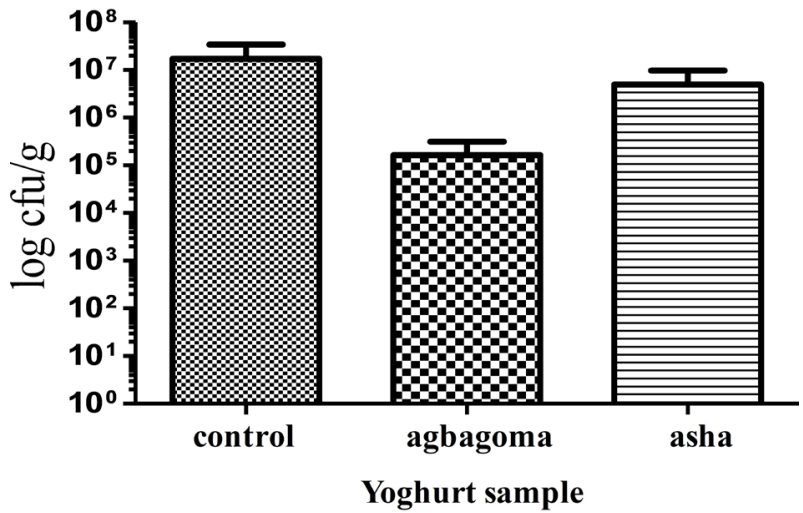

Figure 4. Microbial load of yoghurt samples within the last week of study (week 4). 
containing $0.2 \%$ asha pectin $\left(2.4 \times 10^{7} \pm 11.14 \mathrm{cfu} / \mathrm{g}\right)$ and the control $\left(8.6 \times 10^{7} \pm\right.$ $5.57 \mathrm{cfu} / \mathrm{g})$. Table 3 indicates that yoghurt with $0.2 \%$ agbagoma pectin had the lowest $\mathrm{pH}$ of 3.61 on the fourth week of storage. This $\mathrm{pH}$ was lower than that observed by the control and the sample containing $0.2 \%$ asha pectin which were 4.30 and 4.32 , respectively. The acidic nature of the sample containing agbagoma pectin could have slowed/inhibited the growth of the aerobic microbes.

\section{Conclusion}

Different okra genotypes had varying effects on the physicochemical, sensory and microbial quality of yoghurt. Altering the concentration at which okra pectin is incorporated into yoghurt also had significant effect on the properties evaluated. Addition of okra pectin at $0.2 \%$ improves the consumer acceptability of yoghurt and $0.2 \%$ agbagoma pectin inhibits the proliferation of aerobic microbes. Addition of okra pectin also improves the water holding capacity and reduces whey exudation.

\section{Conflicts of Interest}

The authors declare that there is no conflict of interest.

\section{References}

[1] Woolfe, M.L., Chaplin, M.F. and Otchere, G. (1977) Studies on the Mucilages Extracted from Okra Fruits (Hibiscus esculentus L.) and Baobab Leaves (Adansonia digitata L.). Journal of the Science of Food and Agriculture, 28, 519-529. https://doi.org/10.1002/jsfa.2740280609

[2] Gemede, H.F., Haki, G.D., Beyene, F., Woldegiorgis, A.Z. and Rakshit, S.K. (2016) Proximate, Mineral, and Antinutrient Compositions of Indigenous Okra (Abelmoschus esculentus) Pod Accessions: Implications for Mineral Bioavailability. Food Science \& Nutrition, 4, 223-233. https://doi.org/10.1002/fsn3.282

[3] Kumar, S., Dagnoko, S., Haougui, A., Ratnadass, A., Pasternak, N. and Kouame, C. (2010) Okra (Abelmoschus spp.) in West and Central Africa: Potential and Progress on Its Improvement. African Journal of Agricultural Research, 5, 3590-3598. http://oar.icrisat.org/168

[4] Ndjouenkeu, R., Goycoolea, F., Morrisa, E. and Akingbala, J. (1996) Rheology of Okra (Hibiscus esculentus L.) and Dika Nut (Irvingia gabonensis) Polysaccharides. Carbohydrate Polymers, 29, 263-269. https://doi.org/10.1016/0144-8617(96)00016-1

[5] Sengkhamparn, N., Bakx, E.J., Verhoef, R., Schols, H.A., Sajjaanantakul, T. and Voragen, A.G. (2009) Okra Pectin Contains an Unusual Substitution of Its Rhamnosyl Residues with Acetyl and Alpha-Linked Galactosyl Groups. Carbohydrate Research, 344, 1842-1851. https://doi.org/10.1016/j.carres.2008.11.022

[6] Shittu, T.A. and Olaitan, O.F. (2014) Functional Effects of Dried Okra Powder on Reconstituted Dried Yam Flake and Sensory Properties of Ojojo-A Fried Yam (Dioscorea alata L.) Snack. Journal of Food Science and Technology, 51, 359-364. https://doi.org/10.1007/s13197-011-0513-y

[7] Ghori, M.U., Alba, K., Smith, A.M., Conway, B.R. and Kontogiorgos, V. (2014) Okra Extracts in Pharmaceutical and Food Applications. Food Hydrocolloids, 42, 342-347. https://doi.org/10.1016/j.foodhyd.2014.04.024 
[8] Kpodo, F., Agbenorhevi, J.K., Alba, K., Bingham, R., Oduro, I., Morris, G. and Kontogiorgos, V. (2017) Pectin Isolation and Characterization from Six Okra Genotypes. Food Hydrocolloids, 72, 323-330. https://doi.org/10.1016/j.foodhyd.2017.06.014

[9] Yapo, B.M. (2011) Pectic Substances: From Simple Pectic Polysaccharides to Complex Pectins-A New Hypothetical Model. Carbohydrate Polymers, 86, 373-385. https://doi.org/10.1016/j.carbpol.2011.05.065

[10] Guo, X., Han, D., Xi, H., Rao, L., Liao, X., Hu, X. and Wu, J. (2012) Extraction of Pectin from Navel Orange Peel Assisted by Ultra-High Pressure, Microwave or Traditional Heating: A Comparison. Carbohydrate Polymers, 88, 441-448. https://doi.org/10.1016/j.carbpol.2011.12.026

[11] Urias-Orona, V., Rascón-Chu, A., Lizardi-Mendoza, J., Carvajal-Millán, E., Gardea, A.A. and Ramírez-Wong, B. (2010) A Novel Pectin Material: Extraction, Characterization and Gelling Properties. International Journal of Molecular Sciences, 11, 3686-3695. https://doi.org/10.3390/ijms11103686

[12] Schmelter, T., Wientjes, R., Vreeker, R. and Klaffke, W. (2002) Enzymatic Modifications of Pectins and the Impact on Their Rheological Properties. Carbohydrate Polymers, 47, 99-108. https://doi.org/10.1016/S0144-8617(01)00170-9

[13] Lengsfeld, C., Titgemeyer, F., Faller, G. and Hensel, A. (2004) Glycosylated Compounds from Okra Inhibit Adhesion of Helicobacter Pylori to Human Gastric Mucosa. Journal of Agricultural and Food Chemistry, 52, 1495-1503. https://doi.org/10.1021/jf030666n

[14] Kpodo, F., Agbenorhevi, J.K., Alba, K., Oduro, I., Morris, G. and Kontogiorgos, V. (2018) Structure-Function Relationships in Pectin Emulsification. Food Biophysics, 13, 71-79. https://doi.org/10.1007/s11483-017-9513-4

[15] Datsomor, D.N., Agbenorhevi, J.K., Kpodo, F.M. and Oduro, I.N. (2019) Okra Pectin as Lecithin Substitute in Chocolate. Scientific African, 3, e00070. https://doi.org/10.1016/j.sciaf.2019.e00070

[16] Pohjanheimo, T. and Sandell, M. (2009) Explaining the Liking for Drinking Yoghurt: The Role of Sensory Quality, Food Choice Motives, Health Concern and Product Information. International Dairy Journal, 19, 459-466. https://doi.org/10.1016/j.idairyj.2009.03.004

[17] Mousavi Khaneghah, A., Abhari, K., Eş, I., Soares, M.B., Oliveira, R., Hosseini, H., Rezaei, M., Balthazar, C.F., Silva, R. and Cruz, A.G. (2020) Interactions between Probiotics and Pathogenic Microorganisms in Hosts and Foods: A Review. Trends in Food Science and Technology, 95, 205-218. https://doi.org/10.1016/j.tifs.2019.11.022

[18] Dharmasena, S., Okrent, A. and Capps Jr., O. (2014) Consumer Demand for Greek-Style Yogurt and Its Implications to the Dairy Industry in the United States. https://ageconsearch.umn.edu/record/169799

[19] Pang, Z., Deeth, H., Prakash, S. and Bansal, N. (2016) Development of Rheological and Sensory Properties of Combinations of Milk Proteins and Gelling Polysaccharides as Potential Gelatin Replacements in The Manufacture of Stirred Acid Milk Gels and Yogurt. Journal of Food Engineering, 169, 27-37. https://doi.org/10.1016/j.jfoodeng.2015.08.007

[20] BeMiller, J. (1973) Quince Seed, Psyllium Seed, Flax Seed, and Okra Gums. In: Industrial Gums, Elsevier, Amsterdam, 339-367. https://doi.org/10.1016/B978-0-12-746252-3.50021-6

[21] Hematyar, N., Samarin, A.M., Poorazarang, H. and Elhamirad, A.H. (2012) Effect of 
Gums on Yogurt Characteristics. World Applied Sciences Journal, 20, 661-665.

[22] AOAC (2005) Official Methods of Analysis of the Association of Analytical Chemists International. AOAC, Gaithersburg.

[23] Kpodo, F., Afoakwa, E., Amoa, B., Budu, A. and Saalia, F. (2014) Effect of Ingredient Variation on Microbial Acidification, Susceptibility to Syneresis, Water Holding Capacity and Viscosity of Soy-Peanut-Cow Milk Yoghurt. Journal of Nutritional Health \& Food Engineering, 1, Article ID: 00012. https://doi.org/10.15406/jnhfe.2014.01.00012

[24] Kumar, P. and Mishra, H.N. (2004) Mango Soy Fortified Set Yoghurt: Effect of Stabilizer Addition on Physicochemical, Sensory and Textural Properties. Food Chemistry, 87, 501-507. https://doi.org/10.1016/j.foodchem.2003.12.022

[25] Arioui, F., Ait Saada, D. and Cheriguene, A. (2017) Physicochemical and Sensory Quality of Yogurt Incorporated with Pectin from Peel of Citrus Sinensis. Food Science \& Nutrition, 5, 358-364. https://doi.org/10.1002/fsn3.400

[26] Sahan, N., Yasar, K. and Hayaloglu, A. (2008) Physical, Chemical and Flavour Quality of Non-Fat Yogurt as Affected by a B-Glucan Hydrocolloidal Composite during Storage. Food Hydrocolloids, 22, 1291-1297.

https://doi.org/10.1016/j.foodhyd.2007.06.010

[27] Mao, L., Boiteux, L., Roos, Y.H. and Miao, S. (2014) Evaluation of Volatile Characteristics in Whey Protein Isolate-Pectin Mixed Layer Emulsions under Different Environmental Conditions. Food Hydrocolloids, 41, 79-85.

https://doi.org/10.1016/j.foodhyd.2014.03.025

[28] Ibrahim, A.H. and Khalifa, S.A. (2015) The Effects of Various Stabilizers on Physiochemical Properties of Camel's Milk Yoghurt. Journal of American Science, 11, $15-24$.

[29] Panda, S.H., Naskar, S. and Ray, R. (2006) Production, Proximate and Nutritional Evaluation of Sweet Potato Curd. Journal of Food, Agriculture and Environment, 4, 124-127.

[30] Yildiz, F. (2016) Development and Manufacture of Yogurt and Other Functional Dairy Products. CRC Press, Boca Raton. https://doi.org/10.1201/9781420082081

[31] Ozer, B., Bell, A., Grandison, A. and Robinson, R. (1998) Rheological Properties of Concentrated Yoghurt (Labneh). Journal of Texture Studies, 29, 67-79. https://doi.org/10.1111/j.1745-4603.1998.tb00154.x

[32] Cais-Sokolińska, D., Michalski, M.M. and Pikul, J. (2004) Role of the Proportion of Yoghurt Bacterial Strains in Milk Souring and the Formation of Curd Qualitative Characteristics. Bulletin of the Veterinary Institute in Pulawy, 48, 437-441.

[33] Vahedi, N., Tehrani, M.M. and Shahidi, F. (2008) Optimizing of Fruit Yoghurt Formulation and Evaluating Its Quality during Storage. American-Eurasian Journal of Agricultural \& Environmental Sciences, 3, 922-927. http://citeseerx.ist.psu.edu/viewdoc/summary?doi=10.1.1.605.2295

[34] Kailasapathy, K. (2006) Survival of Free and Encapsulated Probiotic Bacteria and Their Effect on the Sensory Properties of Yoghurt. LWT-Food Science and Technology, 39, 1221-1227. https://doi.org/10.1016/j.lwt.2005.07.013

[35] Panesar, P.S. and Shinde, C. (2012) Effect of Storage on Syneresis, pH, Lactobacillus acidophilus Count, Bifidobacterium bifidum Count of Aloe vera Fortified Probiotic Yoghurt. Current Research in Dairy Sciences, 4, 17-23.

https://scialert.net/abstract/?doi=crds.2012.17.23

https://doi.org/10.3923/crds.2012.17.23 
[36] Obi, T., Henshaw, F. and Atanda, O. (2010) Quality Evaluation of Plain-Stirred Probiotic Yoghurt Produced from Skim and Whole Milk Powder during Refrigerated Storage. Electronic Journal of Environmental, Agricultural \& Food Chemistry, 9, 1203-1213.

http://eds.b.ebscohost.com/eds/detail/detail?vid=0\&sid=6fd7109b-9893-45bb-ad439eaafb5a7156\%40sessionmgr103\&bdata=JnNpdGU9ZWRzLWxpdmU\%3d\#AN=55 $823243 \& \mathrm{db}=\mathrm{a} 9 \mathrm{~h}$ 